\title{
Effect of dry needling on the variability of cardiac frequency in university members
} \section{with temporomandibular dysfunction}

\author{
Efeito do agulhamento a seco na variabilidade da frequência cardíaca em universitários com \\ disfunção temporomandibular \\ Efecto de la punción seca sobre la variabilidad de la frecuencia cardíaca en estudiantes \\ universitarios con trastorno temporomandibular
}

Received: 04/18/2021 | Reviewed: 04/25/2021 | Accept: 04/30/2021 | Published: 05/14/2021

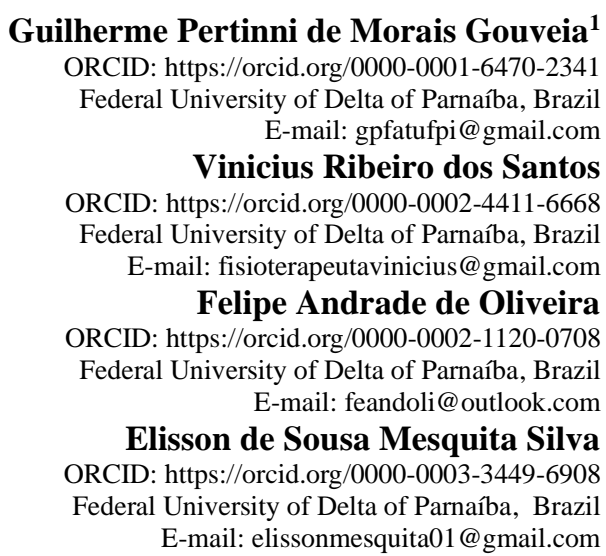

\begin{abstract}
Introduction: Despite the existence of some theories about the effect of Dry Needling on pain, there is still a lack of research using this technique in the treatment of temporomandibular disorder and its repercussions on the autonomic nervous system. Therefore, the aim was to analyze the effect of Dry Needling on the autonomic modulation of university students with temporomandibular disorders. Methods: This is an interventional, inferential study, carried out with university students with temporomandibular disorders. A frequency meter was used before, during, and after the application of the dry needle to verify its short and medium term effect on the autonomic nervous system. For statistical analysis, the ANOVA test was used. Results: Twenty volunteers with an average age of 21.3 years took part in the study, most of them male $(65 \%)$. When the rMSSD and pNN50 indexes were analyzed, an increase was observed during dry needling ( $\mathrm{p}=0.701$ and 0.452 , respectively). However, after application, these indices fell, remaining above the base values. However, the triangular RR and TINN indices showed a constant increase during collection ( $\mathrm{p}=0.578$ and 0.613 , respectively). The high frequency component increased during the technique $(\mathrm{p}=$ $0.860)$, but the same did not happen with the low frequency component $(p=0.693)$, which suffered a constant increase, even with minor variation. Conclusion: The effect of this technique promotes the improvement of the heart rate variability values, maintaining the balance of the autonomic nervous system without generating cardiovascular risks, and its effects were immediate and lasting.
\end{abstract}

Keywords: Dry needling; Temporomandibular joint dysfunction syndrome; Autonomic nervous system; Physiotherapy.

\begin{abstract}
Resumo
Introdução: Apesar da existência de algumas teorias sobre o efeito do Agulhamento Seco na dor, ainda faltam pesquisas que utilizem essa técnica no tratamento da disfunção temporomandibular e suas repercussões no sistema nervoso autônomo. Portanto, o objetivo foi analisar o efeito do Agulhamento a Seco na modulação autonômica de universitários com disfunção temporomandibular. Métodos: Trata-se de um estudo intervencionista, inferencial, realizado com universitários com disfunção temporomandibular. Um frequencímetro foi utilizado antes, durante e após a aplicação da agulha seca para verificar seu efeito a curto e médio prazo sobre o sistema nervoso autônomo.
\end{abstract}

${ }^{1}$ Coordinator of the Research Group in Evaluative and Therapeutic Physiotherapy in Federal University of Delta of Parnaíba. 
Para análise estatística, foi utilizado o teste ANOVA. Resultados: Participaram do estudo 20 voluntários com idade média de 21,3 anos, a maioria do sexo masculino (65\%). Quando analisados os índices rMSSD e pNN50, observou-se aumento durante o agulhamento a seco $(\mathrm{p}=0,701$ e 0,452 , respectivamente). Porém, após a aplicação, esses índices caíram, permanecendo acima dos valores de base. No entanto, os índices triangulares RR e TINN apresentaram aumento constante durante a coleta $(\mathrm{p}=0,578$ e 0,613 , respectivamente). O componente de alta frequência aumentou durante a técnica $(\mathrm{p}=0,860)$, mas o mesmo não aconteceu com o componente de baixa frequência $(\mathrm{p}=0,693)$, que sofreu aumento constante, mesmo com pequena variação. Conclusão: $\mathrm{O}$ efeito dessa técnica promove a melhora dos valores da variabilidade da frequência cardíaca, mantendo o equilíbrio do sistema nervoso autônomo sem gerar riscos cardiovasculares, e seus efeitos foram imediatos e duradouros.

Palavras-chave: Agulhamento a seco; Síndrome da disfunção da articulação temporomandibular; Sistema nervoso autônomo; Fisioterapia.

\section{Resumen}

Introducción: A pesar de la existencia de algunas teorías sobre el efecto de la Punción Seca sobre el dolor, aún existe una falta de investigación con esta técnica en el tratamiento del trastorno temporomandibular y sus repercusiones en el sistema nervioso autónomo. Por tanto, el objetivo fue analizar el efecto de la punción seca en la modulación autonómica de estudiantes universitarios con trastornos temporomandibulares. Métodos: Se trata de un estudio intervencionista, inferencial, realizado con estudiantes universitarios con trastornos temporomandibulares. Se utilizó un medidor de frecuencia antes, durante y después de la aplicación de la aguja seca para comprobar su efecto a corto y medio plazo sobre el sistema nervioso autónomo. Para el análisis estadístico se utilizó la prueba ANOVA. Resultados: participaron del estudio 20 voluntarios con una edad media de 21,3 años, la mayoría varones (65\%). Cuando se analizaron los índices rMSSD y pNN50, se observó un aumento durante la punción seca $(\mathrm{p}=0,701$ y 0,452, respectivamente). Sin embargo, luego de la aplicación, estos índices cayeron, manteniéndose por encima de los valores base. Sin embargo, los índices triangulares RR y TINN mostraron un aumento constante durante la recolección $(\mathrm{p}=0.578$ y 0.613 , respectivamente $)$. El componente de alta frecuencia aumentó durante la técnica $(\mathrm{p}=$ 0,860), pero no sucedió lo mismo con el componente de baja frecuencia ( $\mathrm{p}=0,693)$, que sufrió un aumento constante, incluso con poca variación. Conclusión: El efecto de esta técnica promueve la mejora de los valores de variabilidad de la frecuencia cardíaca, manteniendo el equilibrio del sistema nervioso autónomo, sin generar riesgos cardiovasculares, y sus efectos fueron inmediatos y duraderos.

Palabras clave: Punción seca; Síndrome de disfunción de la articulación temporomandibular; Sistema nervioso autónomo; Fisioterapia.

\section{Introduction}

The busy life of modern society implies an increase in stress levels, and health students are frequently exposed to situations of tension, identifying a high prevalence of symptoms of temporomandibular disorders, as mentioned in the studies by Godinho et al (2019). The temporomandibular joint (TMJ) is composed of the temporal bone, articular disk and condyle of the mandible, connected with various ligaments and muscles that promote protection and movement (Leissner et al., 2020). This joint is part of the stomatognathic system and is defined as a gingival joint capable of producing movements, concomitant with the TMJ on the opposite side (Bordoni \& Varacallo, 2019).

Changes in the TMJ appear when its kinematics are disturbed, leading to dysfunctions in the internal and external articular structures, and neuromuscular imbalances directly affecting the functionality of this joint (Silva et al., 2020; Tuncer, 2020). Based on the natural progression of the internal disorder, functional limitations can take years to be observed, since pain is present, some other very characteristic signs and symptoms become clear, such as crackling, tinnitus, trismus, pain around the eyes, headache, reduced jaw movement, pain when chewing or talking (Bhatnagar et al., 2020; Thambar et al., 2020).

TMJ diseases can result from the joint itself and its dysfunctions are the major reasons for orofacial pain that does not originate from the teeth (Aksu et al., 2019). They can be categorized as muscular, joint, chronic hypomobility and growth disorders that have a negative impact on quality of life, especially in relation to their severity (Foger et al., 2020; Santos et al., 2019). TMJ dysfunction disorders related to myofascial pain are often correlated with hypersensitive tension nodules that cause local muscle contraction, interfering with the range of motion of the joint (Vier et al., 2019).

Within the strategies used for pain and myofascial dysfunction, Dry Needling is one of the common treatment methods, which works by intramuscular insertion of a fine monofilament needle into the trigger point until a first, short and sudden local contraction response is got, suggested as a spinal cord reflex linked to the sensitivity of dysfunctional motor and 
end plates allowing the mechanical effect of the needle to disable the stitch and promote pain relief (Al-Moraissi et al., 2020; Castro-Sánchez et al., 2020; Fernández-de-Las-Peñas \& Nijs, 2019).

These trigger points are painful nodules in the intramuscular region that involves hyperalgesic areas with referred pain, a stretched band and can be classified as active, when they cause sensory symptoms and spontaneous pain, and as latent when pain is only referred to when stimulated (Baraja-Vegas et al., 2019; Dalewski et al., 2019; Fernández-de-las-Peñas \& Dommerholt, 2018).

The heart rate variability (HRV) allows to measure the balance between the sympathetic and parasympathetic nervous system, and the effect of applying this technique promotes repercussions directly on the function of the nervous system, this approach can be supported by the study by Sillevis et al (2019), which measured this response with an automated pupillometric technique and which resulted in immediate feedback to the autonomic nervous system (ANS). The remodeling of this system can be identified with the local responses of muscle contraction, abnormal sweating and temperature (Cao et al., 2020). Despite the existence of some theories about the effect of Dry Needling on pain and adverse effects that can trigger physiological responses and consequently pain relief (Boyce et al., 2020), there is still a lack of research using this technique as a treatment for the public target of this study and its repercussions on the ANS. Therefore, this study becomes an essential tool, besides being able to serve as a basis for further study and technical arsenal for professionals and academics. Therefore, the aim was to analyze the effect of Dry Needling on the autonomic modulation of university students with temporomandibular disorders.

\section{Methodology}

This was an interventional, inferential study of a quantitative character, carried out at the Federal University of Delta do Parnaíba - UFDPar, in the period from March to May 2018. The research was approved by the Research Ethics Committee of the Federal University of Piauí under number 2,283,117.

The research was composed by 20 (software GPower® 3.1.9.4, effect size f: $0.35 ; \alpha$ err prob: 0.05; Power 1- $\beta$ err prob: 0.95 ) university students from UFDPar, for convenience, in the age group of 18 to 30 years old, who had some type of complaint related to TJM dysfuction, verified in the Research's application Diagnostic Criteria for Temporomandibular Disorders (RDC/TMD) and who agreed to take part in the research by signing the informed consent form - IC.

In the first moment, the Research Diagnostic Criteria for Temporomandibular Disorders (RDC/TMD) was applied, composed of 31 aim questions. After obtaining the data and classifying the degrees mild, moderate and severe, the patients with the dysfunction were invited to undergo treatment through the application of Dry Needling, a procedure that comprised the application of sterile monofilament needles to the affected masticatory muscles simultaneously used a frequency meter before, during and after the intervention.

The frequency meter comprises a precision device composed of a strap, installed at the height of the patient's chest and a monitor. This device has the function of checking the heartbeat of an individual, through the analysis of the R-R complex, in any modality. Its use is extremely important, because it is possible to monitor the variations in heart rate during rest or during movement.

The monitoring of the heartbeat is performed by sending the heart rate to a specific monitor, which is saved in computer memory and analyzed using software (Protainer®) and duly monitored by health professionals.

The Polar ${ }^{\circledR}$ rx800 Frequency Meter was fixed with the use of an adjustable elastic strap at the height of the patient's left breast, with the patient being sedated after a five-minute rest. This collection was carried out in three stages, as detailed below: 
The first stage took place with the patient resting in the supine position for five minutes, and it was recommended that the patient neither speak nor perform sudden movements. The 2nd stage comprised the patient remaining in the supine position, submitted to the application of the dry needling technique. The data were collected during the application period and the needles remained at the pain points reported by the patient, with an average duration of ten minutes. The 3rd stage was concluded with the repetition of the procedure performed in the 1st stage.

HRV data were analyzed using the Kubios HRV Analysis® program (version 2.2), which issued a report containing the values of all data and, therefore, were entered a bank to be subsequently applied to statistical tests.

For data analysis, the Kolmogorov-Smirnov test was initially performed, which proved the normality of the variables under study, with a p value greater than 0.05 in all of them, therefore, a symmetrical distribution of the variables was shown. Thus, we used the ANOVA test with Bonferroni's post hoc, standard deviation and confidence interval for statistical analysis $(\mathrm{p} \leq 0.05$ was considered statistically significant).

\section{Results}

Twenty volunteers took part in the study, with a mean age of $21.3 \pm 2.3$ years, median of 21 years, ranging from 18 to 29 years, the majority being male $(65 \%)$. When assessing the clinical profile of the volunteers, it was noticed that the volunteers did not have cardiovascular disease and 95\% did not report lung disease.

\section{Heart rate variability (cardiac autonomy)}

By inferring HRV, using the ANOVA test associated with the Bonferroni post hoc with a 5\% significance level, it was possible to notice that there was no significant difference in autonomic modulation, before, during and after the application of the technique, showing its safety in ANS variability.

When analyzing the SDNN index, it reveals mean of the standard deviations of all normal sinus, an increase in HRV was identified ( $\mathrm{p}=0.640)$, an index that does not allow identifying which system is altered (sympathetic or parasympathetic).

When the rMSSD (the standard deviation of the differences between adjacent normal RR intervals) and pNN50 (percentage of adjacent RR intervals with a difference in duration greater than 50 milliseconds) indexes were analyzed, a considerable increase was observed during the application of dry needling ( $\mathrm{p}=0.701$ and 0.452 , respectively), showing that the technique influences the activation of the parasympathetic system. However, after application, these indices showed a decline, remaining above the base values. However, the triangular indexes RR (interval between sinus beats) and TINN (triangular interpolation of RR intervals) showed a constant increase throughout the collection, although this value is not very variable ( $\mathrm{p}$ $=0.578$ and 0.613 , respectively), which can infer that there was a small parasympathetic response. This result allows us to state that the maneuver increased the heart rate variability, without statistical significance, as shown in Table 1. 
Table 1: Analysis of heart rate variability (time domain), before, during and after the Dry Needling technique, Parnaíba, 2018.

\begin{tabular}{lccccc}
\hline \multicolumn{1}{c}{ Variables } & $\begin{array}{c}\text { Mean before } \\
\text { (SD) }\end{array}$ & $\begin{array}{c}\text { Mean during } \\
\text { (SD) }\end{array}$ & $\begin{array}{c}\text { Mean after } \\
\text { (SD) }\end{array}$ & $\boldsymbol{p}$ value & $\begin{array}{c}\text { Mean difference } \\
(\mathbf{9 5 \%} \text { CI })\end{array}$ \\
\hline Mean R-R & $546,0( \pm 157,3)$ & $624,0( \pm 159,1)$ & $624,0( \pm 135,1)$ & $0,409^{\dagger}$ & $-64,1(-181,8-53,5)$ \\
Rmssd & $42,4( \pm 29,6)$ & $49,3( \pm 25,0)$ & $44,8( \pm 23,6)$ & $0,701^{\dagger}$ & $-6,9(-27,3-13,5)$ \\
SDNN & $40,4( \pm 17,9)$ & $44,8( \pm 17,9)$ & $44,9( \pm 18,8)$ & $0,640^{\dagger}$ & $-4,64(-18,8-9,5)$ \\
pNN50 & $20,4( \pm 19,7)$ & $27,3( \pm 19,9)$ & $21,4( \pm 15,8)$ & $0,452^{\dagger}$ & $-6,8(-21,3-7,6)$ \\
RR triangular & $9,2( \pm 2,9)$ & $10,1( \pm 3,3)$ & $10,2( \pm 3,4)$ & $0,578^{\dagger}$ & $-0,8(-3,4-1,7)$ \\
& & & & & \\
TINN & $194,5( \pm 71,5)$ & $215,9( \pm 70,3)$ & $217,2( \pm 98,2)$ & $0,613^{\dagger}$ & $-21,4(-84,6-41,8)$ \\
\hline
\end{tabular}

Legend: HRV: Heart Rate Variability; SD: Standard Deviation ( \pm ); SDNN: standard deviation of all normal RR intervals recorded in a time interval, expressed in ms; pNN50: represents the percentage of adjacent RR intervals with a difference in duration greater than 50ms; rMSSD: square root of the mean of the square of the differences between the adjacent normal RR intervals, in an interval, expressed in ms. RRtri - triangular index; TINN - triangular interpolation of RR intervals. $†$ There was no statistical difference (ANOVA post hoc Bonferroni). CI: confidence interval.

Source: Gouveia, et al., (2018).

The comparison of the values of the HRV variables in the frequency domain, fast Fourier transform, revealed that there were no significant differences between the collection phases. However, when performing a qualitative spectral analysis of the HRV parameters, it was observed that the high frequency component (high frequency - HF) increased during the technique ( $\mathrm{p}=0.860)$, not the same with the low frequency component (low frequency - LF) $(\mathrm{p}=0.693)$, which underwent a constant increase, even with little variation, showing greater performance of the vagus nerve on the heart, greater performance of the parasympathetic. When the LF / HF ratio was analyzed, a considerable decrease in its value was identified during needle application, characterizing the sympathovagal balance over the heart as an increase in parasympathetic action and a reduction in sympathetic function $(\mathrm{p}=0.195)$ (Table 2$)$.

Table 2: Analysis of heart rate variability (frequency domain) by the Fast Fourier transform, before, during and after the Dry Needling technique, Parnaíba, 2018.

\begin{tabular}{|c|c|c|c|c|c|}
\hline Variables & $\begin{array}{l}\text { Mean before } \\
\text { (SD) }\end{array}$ & $\begin{array}{l}\text { Mean during } \\
\text { (SD) }\end{array}$ & $\begin{array}{l}\text { Mean after } \\
\text { (SD) }\end{array}$ & $p$ value & $\begin{array}{l}\text { Mean difference } \\
(95 \% \mathrm{CI})\end{array}$ \\
\hline $\mathrm{HF}$ & $6,1( \pm 1,6)$ & $6,3( \pm 1,1)$ & $6,2( \pm 1,1)$ & $0,860^{\dagger}$ & $-0,2(-1,1-0,8)$ \\
\hline $\mathrm{LF}$ & $6,3( \pm 0,7)$ & $6,4( \pm 0,9)$ & $6,6( \pm 1,0)$ & $0,693^{\dagger}$ & $-0,1(-0,7-0,6)$ \\
\hline $\mathrm{LF} / \mathrm{HF}$ & $2,6( \pm 2,7)$ & $1,6( \pm 1,6)$ & $1,8( \pm 1,1)$ & $0,195^{\dagger}$ & $1,0(-0,4-2,6)$ \\
\hline
\end{tabular}

Legend: SD: Standard Deviation $( \pm)$; HF: high frequency (parasympathetic); LF: low frequency (sympathetic). $\dagger$ There was no statistical difference (ANOVA post hoc Bonferroni). CI: confidence interval.

Source: Gouveia, et al., (2018).

When inferring data on HRV, before, during and after, the application of the Dry Needling protocol for TMD, regarding the SD1 and SD2 variables of the Poincaré geometric index, using the ANOVA test associated with the Bonferroni post hoc with significance level of $5 \%$, there was no statistical significance for the values of SD1 $(p=0.700)$ and SD2 $(p=$ 0.488). Such results confirm the safety in the use of the technique given that it did not generate negative influences on the cardiovascular system, as shown in Table 3. 
Table 3: Analysis of heart rate variability by poincaré plotting, before, during and after the Dry Needling technique, Parnaíba, 2018.

\begin{tabular}{lccccc}
\hline Variables & $\begin{array}{c}\text { Mean before } \\
(\mathbf{S D})\end{array}$ & $\begin{array}{c}\text { Mean during } \\
(\mathbf{S D})\end{array}$ & $\begin{array}{c}\text { Mean after } \\
(\mathbf{S D})\end{array}$ & $\boldsymbol{p}$ value & $\begin{array}{c}\text { Mean difference } \\
\mathbf{( 9 5 \%} \text { CI })\end{array}$ \\
\hline $\mathrm{SD} 1$ & $30,0( \pm 20,9)$ & $34,9( \pm 17,8)$ & $31,7( \pm 1,7)$ & $0,700^{\dagger}$ & $-4,8(-19,3-9,6)$ \\
$\mathrm{SD} 2$ & $47,2( \pm 17,0)$ & $52,0( \pm 20,3)$ & $54,7( \pm 21,9)$ & $0,488^{\dagger}$ & $-4,8(-20,3-10,7)$ \\
\hline
\end{tabular}

Legend: SD: Standard Deviation $( \pm)$; SD1: standard deviation of the instantaneous beat-to-beat variability; SD2: long-term standard deviation of continuous R-R intervals. $\uparrow$ There was no statistical difference (ANOVA post hoc Bonferroni). CI: confidence interval. Source: Gouveia, et al., (2018).

\section{Discussion}

In the present study, Dry Needling therapies in university students with temporomandibular disorders showed an increase in sympathetic activation during application and a reduction afterwards, with the constant growth of triangular RR and TINN indexes showing a parasympathetic response to needle insertion, and how much at frequency a sympathetic-vagal balance was observed.

With the needle applied to the trigger point, a first local contraction response is got, defined as the soft and sudden contraction of a stretched trigger point band (Fernández-de-Las-Peñas \& Nijs, 2019). The dysfunctional motor end plates in the skeletal muscle release an excessive amount of acetylcholine in the synaptic cleft, causing muscle contraction, and this release of acetylcholine starts spontaneous electrical activity in the muscle fibers (Liu et al., 2020).

The needle acts through mechanoreceptors and gap junctions $\left(\mathrm{Ca}^{2+}\right)$ as a mechanical wave that stimulates the other physiological activities in the body coming to manifest itself in the blood flow through the mechanical pressure wave (Matic \& Bojic, 2020). The initial increase in SDNN and pNN50 indices can be explained by nociceptors housed under the skin, such as Pacini corpuscles, Ruffini corpuscles and mechanoreceptors that, when activated, promote acute pain through the larger, faster and myelinated A- $\delta$ fibers (Lai \& Khachemoune, 2020).

After the muscle contraction response, the movement performed up and down with the needle can decrease the amplitude and frequency of spontaneous electrical activities of the trigger point, which corroborates the sympathetic decline presented in the generated SDNN and rMSSD indexes by the decrease in acetylcholine levels to the response at the neuromuscular junction ensuring the break of the local contracture cycle (Mendigutia-Gómez et al., 2016; Mullins et al., 2019).

This decrease in the local muscle contraction response is even more clear in the study by Baraja-Vegas et al (2019), which, through electromyography, was reduced after consecutive muscle contraction responses triggered during the application of dry needling. In the study carried out by Sillevis and his collaborators (2019), they showed in real time the effect in dry of needling in healthy individuals, showing an immediate response in the autonomic nervous system with placing paravertebral needles in the C7 - T3 segments, in which a significant increase in sympathetic nervous system activity that continues for up to 18 minutes.

Regarding pain after needling, Martín-Pintado-Zugasti et al (2018) showed a higher prevalence and intensity of pain after applying Dry Needling in most patients with neck pain with active trigger points in the upper trapezius region. when multiple insertions of the deep dry needling were performed, muscle contraction responses were achieved, differing from the other group that received only a single needle insertion.

The study produced by Uchida et al (2019) investigated the effects of deep pain sensations by stimulating acupuncture on the heart rate and autonomic nervous system functions of 40 healthy individuals and showed that there was a reduction in heart rate with a dominance of the system parasympathetic nervous system during the application of the technique, the domain 
of this result can be understood by the projection of the nerve impulses generated by the action of the needle stimulus that are transmitted by the $\mathrm{C}$ fibers that project to the hypothalamus and brain stem, and not by the sensory cortex.

Another study carried out by Uchida et al (2020) aimed to determine the relationships of deep acupuncture in cortical relaxation and surveillance based on encephalograms and heart rate and the autonomic nervous system. Their findings showed that HRV indices showed that SNA changed for parasympathetic dominance regardless of the subjective feeling of comfort or discomfort of the technique.

The investigation of the effect of trigger point compression stimulation was carried out by another study that revealed increased parasympathetic competence, stating that different stimuli from the application of dry needles when applied to these tension points provoke this same response (Morikawa et al., 2017). These findings corroborate those of the present study, in which a small parasympathetic response was observed during the application of the Dry Needle with constant increase, but no other recent studies were found that tested the effects of the Dry Needle on autonomic modulation in patients with TMD.

According to Yoji Kitagawa (2020) when carrying out his research on the spectral analysis of heart rate variability during acupuncture at the trigger point of three muscles, one of which was the masseter muscle, and this is involved with the TMJ joint, in its findings the HF component increased transiently, however there were no statistical differences in heart rate variability or in the LF / HF ratio, suggesting that stimulation by acupuncture in the muscles studied transiently increases parasympathetic nerve activity, confirming what was found in the present study, when the LF / HF ratio analysis was performed, we got an important reduction showing that there was a noticeable transition in the sympathetic-vagal balance, even though the LF component increased to balance the increase in HF, however, there was no significant difference according to the statistical data, so also when the frequency variability is verified cardiac.

\section{Conclusion}

This study is unprecedented, as it is the first to investigate the effect of Dry Needling on heart rate variability in people with TMD, using a detailed spectral analysis of the time and frequency domain, and poincaré plot. Thus, it is concluded that the effect of this technique promotes the improvement of the heart rate variability values while maintaining an ANS balance; According to the findings, this technique does not generate cardiovascular risks, and its effects were immediate and lasting. It is suggested that future research seeks to expand the use of dry needling in association with other therapeutic approaches in the treatment of different TMD conditions.

\section{References}

Aksu, Ö., Doğan, Y. P., Çağlar, N. S., \& Şener, B. M. (2019). Comparison of the efficacy of dry needling and trigger point injections with exercise in temporomandibular myofascial pain treatment. Turkish Journal of Physical Medicine and Rehabilitation, 65(3), 228-235. https://doi.org/10.5606/tftrd.2019.1802

Al-Moraissi, E. A., Alradom, J., Aladashi, O., Goddard, G., \& Christidis, N. (2020). Needling therapies in the management of myofascial pain of the masticatory muscles: A network meta-analysis of randomised clinical trials. Journal of Oral Rehabilitation, 47(7), 910-922. https://doi.org/10.1111/joor.12960

Baraja-Vegas, L., Martín-Rodríguez, S., Piqueras-Sanchiz, F., Faundez-Aguilera, J., Bautista, I. J., Barrios, C., \& Fernández-De-Las-Peñas, C. (2019). Localization of Muscle Edema and Changes on Muscle Contractility after Dry Needling of Latent Trigger Points in the Gastrocnemius Muscle. Pain Medicine (United States), 20(7), 1387-1394. https://doi.org/10.1093/pm/pny306

Bhatnagar, S., Knopp, H. E., \& Azuh, O. (2020). Temporoman - dibular Joint Dysfunction. In Essentials of Physical Medicine and Rehabilitation (Fourth Edi). Elsevier Inc. https://doi.org/10.1016/B978-0-323-54947-9.00114-0

Bordoni, B., \& Varacallo, M. (2019). Anatomy, Head and Neck, Temporomandibular Joint. In StatPearls (Issue April). https://www.ncbi.nlm.nih.gov/books/NBK538486/?report=printable

Boyce, D., Wempe, H., Campbell, C., Fuehne, S., Zylstra, E., Smith, G., Wingard, C., \& Jones, R. (2020). Adverse Events Associated With Therapeutic Dry Needling. International Journal of Sports Physical Therapy, 15(1), 103-113. https://doi.org/10.26603/ijspt20200103

Cao, L., Gao, Y., Wu, K., Li, Y., Chen, C., \& Yuan, S. (2020). Sympathetic hyperinnervation in myofascial trigger points. Medical Hypotheses, 139 , 109633. 
https://doi.org/10.1016/j.mehy.2020.109633

Castro-Sánchez, A. M., Garcia-López, H., Fernández-Sánchez, M., Perez-Marmol, J. M., Leonard, G., Gaudreault, N., Aguilar-Ferrándiz, M. E., \& MataránPeñarrocha, G. A. (2020). Benefits of dry needling of myofascial trigger points on autonomic function and photoelectric plethysmography in patients with fibromyalgia syndrome. Acupuncture in Medicine, OO(0). https://doi.org/10.1136/acupmed-2017-011504

Dalewski, B., Kamińska, A., Szydłowski, M., Kozak, M., \& Sobolewska, E. (2019). Comparison of early effectiveness of three different intervention methods in patients with chronic orofacial pain: A randomized, controlled clinical trial. Pain Research and Management, 2019, 9-11. https://doi.org/10.1155/2019/7954291

Fernández-de-las-Peñas, C., \& Dommerholt, J. (2018). International consensus on diagnostic criteria and clinical considerations of myofascial trigger points: A delphi study. Pain Medicine (United States), 19(1), 142-150. https://doi.org/10.1093/pm/pnx207

Fernández-de-Las-Peñas, C., \& Nijs, J. (2019). Trigger point dry needling for the treatment of myofascial pain syndrome: current perspectives within a pain neuroscience paradigm. Journal of Pain Research, Volume 12, 1899-1911. https://doi.org/10.2147/JPR.S154728

Foger, D., Peralta-Mamani, M., \& Santos, P. S. da S. (2020). Impact of temporomandibular disorders on quality of life. Fisioterapia Em Movimento, 33, 1-10. https://doi.org/10.1590/1980-5918.033.ao20

Godinho, D. C. A., Melo, S. R., Lemos, M. E. S., \& Furlan, R. M. M. M. (2019). Correlação entre sintomas de disfunção temporomandibular, hábitos orais deletérios e sintomas de estresse em estudantes universitários. Distúrbios Da Comunicação, 31(3), 481-492. https://doi.org/10.23925/21762724.2019v31i3p481-492

Lai, Y. C., \& Khachemoune, A. (2020). Pain-less injection: principles and pearls. Archives of Dermatological Research, $0123456789,2-4$. https://doi.org/10.1007/s00403-020-02075-0

Leissner, O., Maulén-Yáñez, M., Meeder-Bella, W., León-Morales, C., Vergara-Bruna, E., \& González-Arriagada, W. A. (2020). Assessment of mandibular kinematics values and its relevance for the diagnosis of temporomandibular joint disorders. Journal of Dental Sciences, xxxx. https://doi.org/10.1016/j.jds.2020.05.015

Liu, L., Huang, Q. M., Liu, Q. G., Nguyen, T. T., Yan, J. Q., \& Bo, C. Z. (2020). Relationship between muscle spindles and myofascial trigger spots according to Hoffmann reflex pathway and tissue morphology characteristics in a rat model. Acupuncture in Medicine, 38(2), 109-116. https://doi.org/10.1136/acupmed2017-011626

Martín-Pintado-Zugasti, A., Fernández-Carnero, J., León-Hernández, J. V., Calvo-Lobo, C., Beltran-Alacreu, H., Alguacil-Diego, I., Gallego-Izquierdo, T., \& Pecos-Martin, D. (2018). Postneedling Soreness and Tenderness After Different Dosages of Dry Needling of an Active Myofascial Trigger Point in Patients With Neck Pain: A Randomized Controlled Trial. PM and R, 10(12), 1311-1320. https://doi.org/10.1016/j.pmrj.2018.05.015

Matic, Z., \& Bojic, T. (2020). Acupuncture, autonomic nervous system and biophysical origin of acupuncture system. Vojnosanitetski PregledMilitary Medical and Pharmaceutical Journal of Serbia, 77(1), 79-86. https://doi.org/10.2298/vsp170818016m

Mendigutia-Gómez, A., Martín-Hernández, C., Salom-Moreno, J., \& Fernández-de-las-Peñas, C. (2016). Effect of Dry Needling on Spasticity, Shoulder Range of Motion, and Pressure Pain Sensitivity in Patients With Stroke: A Crossover Study. Journal of Manipulative and Physiological Therapeutics, 39(5), 348-358. https://doi.org/10.1016/j.jmpt.2016.04.006

Morikawa, Y., Takamoto, K., Nishimaru, H., Taguchi, T., Urakawa, S., Sakai, S., Ono, T., \& Nishijo, H. (2017). Compression at myofascial trigger point on chronic neck pain provides pain relief through the prefrontal cortex and autonomic nervous system: A pilot study. Frontiers in Neuroscience, 11(APR), 1-13. https://doi.org/10.3389/fnins.2017.00186

Mullins, J. F., Nitz, A. J., \& Hoch, M. C. (2019). Dry needling equilibration theory: A mechanistic explanation for enhancing sensorimotor function in individuals with chronic ankle instability. Physiotherapy Theory and Practice, O(0), 1-10. https://doi.org/10.1080/09593985.2019.1641870

Santos, R. Dos, Montibeller, G. V., Campos, M. L., \& Oliveira, K. C. (2019). Interação entre disfunções temporomandibulares, diagnósticos e modalidades de tratamento. Revista Da Faculdade de Odontologia - UPF, 24(1), 155-161. https://doi.org/10.5335/rfo.v24i1.9003

Sillevis, R., Van Duijn, J., Shamus, E., \& Hard, M. (2019). Time effect for in-situ dry needling on the autonomic nervous system, a pilot study. Physiotherapy Theory and Practice, O(00), 1-9. https://doi.org/10.1080/09593985.2019.1644691

Silva, N. M. N. da, Bezerra, L. Â., \& Silva, N. M. R. da. (2020). Eficácia da terapia manual no tratamento das disfunções temporomandibulares. Revista FisiSenectus, 7(2), 53. https://doi.org/10.22298/rfs.2019.v7.n2.5045

Thambar, S., Kulkarni, S., Armstrong, S., \& Nikolarakos, D. (2020). Botulinum toxin in the management of temporomandibular disorders: a systematic review. British Journal of Oral and Maxillofacial Surgery, 58(5), 508-519. https://doi.org/10.1016/j.bjoms.2020.02.007

Tuncer, A. (2020). Kinesiology of the temporomandibular joint. In Comparative Kinesiology of the Human Body (Vol. 41, pp. 285-302). Elsevier. https://doi.org/10.1016/B978-0-12-812162-7.00014-X

Uchida, C., Waki, H., Minakawa, Y., Tamai, H., Miyazaki, S., Hisajima, T., \& Imai, K. (2019). Effects of Acupuncture Sensations on Transient Heart Rate Reduction and Autonomic Nervous System. 31(3), 176-185. https://doi.org/10.1089/acu.2019.1350

Uchida, C., Waki, H., Minakawa, Y., Tamai, H., Miyazaki, S., Hisajima, T., \& Imai, K. (2020). Acupuncture Relaxation, Vigilance Stage, and Autonomic Nervous System Function: A Comparative Study of Their Interrelationships. Medical Acupuncture, OO(0). https://doi.org/10.1089/acu.2020.1420

Vier, C., Almeida, M. B. de, Neves, M. L., Santos, A. R. S. dos, \& Bracht, M. A. (2019). The effectiveness of dry needling for patients with orofacial pain associated with temporomandibular dysfunction: a systematic review and meta-analysis. Brazilian Journal of Physical Therapy, 23(1), 3-11. https://doi.org/10.1016/j.bjpt.2018.08.008 
Research, Society and Development, v. 10, n. 5, e49510515198, 2021

(CC BY 4.0) | ISSN 2525-3409 | DOI: http://dx.doi.org/10.33448/rsd-v10i5.15198

Yoji Kitagawa. (2020). Spectral Analysis of Heart Rate Variability During Trigger-Point Acupuncture of Various Muscles. Published Online, 20. https://doi.org/https://doi.org/10.1089/acu.2020.1414 